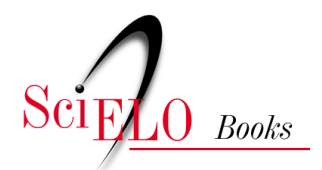

\title{
A inserção urbana de empreendimentos do Programa Minha Casa Minha Vida em João Pessoa, Campina Grande e Patos, na Paraíba
}

\author{
Lívia Miranda \\ Demóstenes Moraes \\ Juliana Peixoto de Araújo
}

\section{SciELO Books / SciELO Livros / SciELO Libros}

MIRANDA, L, MORAES, D., and ARAÚJO, J. P. A inserção urbana de empreendimentos do Programa Minha Casa Minha Vida em João Pessoa, Campina Grande e Patos, na Paraíba. In.: MAIA, D. S., and MARAFON, G. J., eds. O programa Minha Casa Minha Vida: habitação e produção do espaço urbano em diferentes escalas e perspectivas [online]. Rio de Janeiro: EDUERJ, 2020, pp. 141-167. ISBN: 978-65-00-03029-7.

https://doi.org/10.7476/9786500030297.0006.

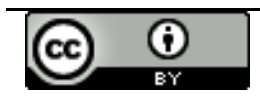

All the contents of this work, except where otherwise noted, is licensed under a Creative Commons Attribution 4.0 International license.

Todo o conteúdo deste trabalho, exceto quando houver ressalva, é publicado sob a licença Creative Commons Atribição 4.0.

Todo el contenido de esta obra, excepto donde se indique lo contrario, está bajo licencia de la licencia Creative Commons Reconocimento 4.0. 


\title{
A inserção urbana de empreendimentos do Programa Minha Casa Minha Vida em João Pessoa, Campina Grande e Patos, na Paraíba
}

\author{
Livia Miranda \\ Demóstenes Moraes \\ Juliana Peixoto de Araújo
}

\section{Consideraçóes iniciais}

Os avanços institucionais nas últimas duas décadas em relação à questão habitacional no Brasil foram significativos. Foram elaborados a Política Nacional de Habitação (PNH), em 2004, e o Plano Nacional de Habitação (PlanHab), em 2008. Também foram instituídos em 2005, pela Lei Federal n..$^{\circ} 11.124$, o Sistema Nacional de Habitaçáo de Interesse Social (SNHIS) e o Fundo Nacional de Habitação de Interesse Social (FNHIS). Além destes instrumentos, dois programas federais, o Programa de Aceleração do Crescimento (PAC), lançado em 2007, e o Programa Minha Casa Minha Vida (PMCMV), criado em 2009, foram responsáveis pela provisão de soluçóes habitacionais em escala inédita.

O PMCMV, concebido pelos Ministérios da Casa Civil e da Fazenda em parceria com grandes construtoras, instituído pela Lei Federal n. ${ }^{\circ}$ 11.977/2009, tinha como objetivo fundamental enfrentar as repercussóes no País da crise econômica global de 2008, servindo como medida anticíclica a partir do investimento na construçáo civil para a ampliaçáo da oferta de habitaçôes, com repercussóes, ainda, na geração de empregos e nas dinâmicas imobiliárias. O programa foi implementado contando com a combinação de 
subsídios e financiamentos e em parceria com estados, municípios, empresas e entidades sem fins lucrativos.

O PMCMV, em função do volume de recursos e abrangência de intervenção e, também, em decorrência dos subsídios para alcançar a população de baixa renda, teve repercussóes econômicas e sociais expressivas, com mais de 5 milhóes de contratos assinados em 9 anos (2009-18), número acima dos 4,8 milhóes de contratos realizados pelo Banco Nacional de Habitação (BNH) em 22 anos. O programa possibilitou, ainda, o estímulo ao mercado privado para o atendimento da populaçáo de baixa renda e a criação de um marco regulatório para a regularização fundiária de áreas ocupadas. Mesmo com estes avanços, diversas avaliaçóes do PMCMV têm apontado para problemas em relação aos empreendimentos, principalmente os da Faixa 1, voltados à população de baixa renda.

Vários estudos para a avaliação do PMCMV foram realizados, entre eles é importante destacar o conjunto de pesquisas decorrentes do edital lançado pelo Conselho Nacional de Desenvolvimento Científico e Tecnológico (CNPq) e Ministério das Cidades em 2012, resultando na avaliação de empreendimentos do programa em 22 municípios de 6 estados. As instituiçóes envolvidas na pesquisa constituíram a Rede Cidade e Moradia e, a partir dos estudos e avaliaçóes, apontaram questóes importantes em relação aos empreendimentos voltados à população de baixa renda, na Faixa 1 do programa, entre as quais destacam-se: (i) a prevalência de um padrão de produção de soluçóes homogêneas, nos âmbitos arquitetônico, urbanístico e construtivos, em decorrência de obstáculos normativos e dos interesses das construtoras; (ii) a periferização dos empreendimentos, em áreas com insuficiência de serviços, equipamentos e oportunidades socioeconômicas; (iii) a flexibilização das legislaçóes locais para a aprovação dos projetos, incluindo a ampliaçáo dos perímetros urbanos; (iv) a predominância do condomínio para a gestão dos empreendimentos pelos moradores, que tem acarretado dificuldades na manutenção de espaços coletivos, conflitos de vizinhança e vulnerabilidade para atuação de facçóes do narcotráfico e de milícias (Santo Amore et al., 2015).

Em relação à inserção urbana, os empreendimentos do PMCMV da Faixa 1 foram executados, em sua maioria, sem atentar às especificidades dos municípios, com insuficiente integração ao tecido urbano local. Estão localizados predominantemente em áreas menos valorizadas das cida- 
des, marcadas por alguma forma de precariedade e pela insuficiência de infraestrutura, serviços urbanos e de oportunidades socioeconômicas. Vale ressaltar as grandes dimensóes dos empreendimentos para viabilizar a reprodução de muitas unidades. A omissão dos governos locais no tocante ao estabelecimento de regras e controle do uso e ocupação do solo contribuiu à ampliação do processo de periferização e espraiamento da área urbana, quando muitas vezes há diversos vazios na malha urbana consolidada, com maior oferta de serviços.

As crises econômicas e políticas que se sucederam entre 2015 e 2016 resultaram na diminuiçáo drástica dos investimentos em políticas sociais (Cardoso e Denaldi, 2018, p. 12). É muito provável que náo haja programas federais habitacionais que alcancem de modo significativo a população de baixa renda nos próximos anos, em um contexto de predominância de políticas pró-mercado.

Todas as questóes levantadas sobre o PMCMV serviram de estímulo para a proposiçấo da Pesquisa: "Empreendimentos Habitacionais em Espaços Periféricos: Desafios para o Planejamento Territorial Integrado" (Miranda, 2018). Buscou-se por meio dessa pesquisa desenvolver análises sobre a inserçáo urbana e a qualidade arquitetônica e urbanística dos empreendimentos produzidos pelo PMCMV em alguns municípios paraibanos.

Alguns resultados da pesquisa serão apresentados nesse artigo que está estruturado em três partes, além dessas consideraçóes iniciais: na primeira, apresenta-se algumas consideraçóes metodológicas e os parâmetros de avaliaçâo utilizados; na segunda discute-se os principais impactos da inserçáo de cinco empreendimentos os casos de João Pessoa, Campina Grande e Patos, de forma associada com entrevistas que coletaram a impressão dos moradores. Por fim, são apresentadas algumas consideraçôes finais.

\section{Algumas consideraçôes metodológicas}

A pesquisa tomou como referências o "Estudo sobre a formas de provisão da moradia e seus impactos na reconfiguração espacial das metrópoles", desenvolvido no âmbito da rede INCT Observatório das Metrópoles e a pesquisa da Rede Cidade e Moradia (Santo Amore et al., 2015). Para complementar as análises das características arquitetônicas e urbanísticas dos empreendimentos, novos indicadores foram acrescentados. Além dos obje- 
tivos propostos inicialmente, foi possível, ainda, construir uma adaptação metodológica para adequar a aplicaçáo de instrumentos, indicadores e parâmetros para os casos de cidades intermediárias e para avaliar os impactos nas periferias das cidades paraibanas, caracterizadas por fragilidades ambientais e pela precariedade das condiçóes socioespaciais.

A análise da provisão de empreendimentos habitacionais do PMCMV no estado da Paraíba estruturou-se em três escalas: (i) na escala do estado, foram observadas as estratégias de promoção do programa, as modalidades e a sua distribuição territorial; (ii) na escala dos municípios foram analisados três estudos de caso: João Pessoa, Campina Grande e Patos - municípios que concentravam $70 \%$ dos empreendimentos promovidos para a população mais vulnerável do Estado; (iii) na escala do empreendimento foram analisados cinco casos assim distribuídos - dois em João Pessoa (Solar das Mangueiras e Morada dos Hibiscos); dois em Campina Grande, com quatro condomínios cada (Residenciais Major Veneziano I, II, III, IV e Residenciais Dona Lindu I, II, III, IV) e um em Patos, com dois empreendimentos (Residenciais Vista da Serra I, II).

O porte das cidades estudadas implicou na necessidade de adequaçóes metodológicas, em funçáo do diâmetro da mancha urbana (menores do que nos casos de estudo paulistas e cariocas) e das modalidades de deslocamento, que tinham implicação direta sobre o tempo de deslocamento, distâncias a equipamentos, entre outros parâmetros.

Após a seleção dos municípios, foram definidos os empreendimentos do PMCMV que seriam analisados. Para o desenvolvimento do estudo, foram utilizados o conjunto de variáveis da pesquisa nacional (Rede Cidade e Moradia), observando: (i) a diversidade no porte dos empreendimentos; (ii) o tempo de ocupação, dando preferência aos que tivessem no mínimo 1 ano de ocupação; (iii) as faixas de renda a que se destinavam, priorizando aqueles da Faixa 1; (iv) observação da produção a partir de modalidades diferentes do programa; (v) a inserção na cidade, considerando a localização e conexóes com a malha urbana e o acesso dos moradores a equipamentos e serviços urbanos.

Foram selecionados empreendimentos com características, padróes de inserção e portes distintos, listados no Quadro 1, discriminados por faixa, número de unidades, tipologias, fase, ano de entrega e modalidade. 
Quadro 1 - Características dos empreendimentos selecionados por município.

\begin{tabular}{|c|c|c|c|c|c|c|c|}
\hline$\underset{\mathrm{U}}{\stackrel{\mathrm{U}}{\mathrm{O}}}$ & 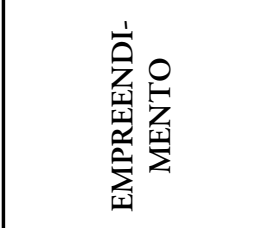 & 发 & 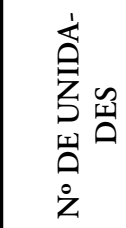 & \begin{tabular}{l}
$j$ \\
\multirow{3}{5}{} \\
0 \\
0 \\
0 \\
$\vdots$
\end{tabular} & 占 & 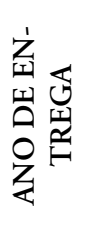 & 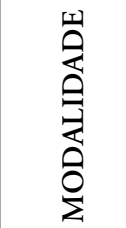 \\
\hline \multirow{2}{*}{$\begin{array}{l}\text { João } \\
\text { Pessoa }\end{array}$} & Morada dos Hibiscos & 1 & 224 & Apartamento & 1 & 2015 & Entidades \\
\hline & Solar das Mangueiras & 1 & 165 & Casa & 1 & 2010 & Entidades \\
\hline \multirow{8}{*}{$\begin{array}{l}\text { Campina } \\
\text { Grande }\end{array}$} & Major Veneziano I & 1 & 496 & Apartamento & 2 & 2013 & Urbano \\
\hline & Major Veneziano II & 1 & 496 & Apartamento & 2 & 2013 & Urbano \\
\hline & Major Veneziano III & 1 & 496 & Apartamento & 2 & 2013 & Urbano \\
\hline & Major Veneziano IV & 1 & 496 & Apartamento & 2 & 2014 & Urbano \\
\hline & Dona Lindú I & 2 & 240 & Apartamento & 1 & 2011 & Urbano \\
\hline & Dona Lindú II & 2 & 240 & Apartamento & 1 & 2011 & Urbano \\
\hline & Dona Lindú III & 2 & 256 & Apartamento & 1 & 2011 & Urbano \\
\hline & Dona Lindú IV & 2 & 208 & Apartamento & 1 & 2011 & Urbano \\
\hline \multirow{2}{*}{ Patos } & Vista da Serra I & 1 & 136 & Casa & 1 & 2011 & Urbano \\
\hline & Vista da Serra II & 1 & 109 & Casa & 2 & 2014 & Urbano \\
\hline
\end{tabular}

Fonte: Ministério das Cidades (Brasil, 2015 e Miranda, 2018).

No Quadro 2, estão relacionados os instrumentos de análise, com as dimensôes e indicadores trabalhados na pesquisa.

1 Os empreendimentos de João Pessoa e Campina Grande se configuram em condomínios fechados (cercado por muros com guarita e porta única de entrada) e os de Patos, condomínios abertos. 
Quadro 2 - Instrumentos de análise - Dimensóes e Indicadores

\begin{tabular}{l|l}
\hline DIMENSÓES & INDICADORES \\
\hline Condiçóes Socioeconômicas e Inserçáo no & Perfil Socioeconômico da Família \\
\cline { 2 - 2 } Mundo do Trabalho & Situação de Trabalho \\
\hline \multirow{2}{*}{ Direito à Cidade e Inserçáo Urbana } & Condiçôes de Moradia \\
\cline { 2 - 2 } & Mobilidade Urbana \\
\cline { 2 - 2 } Trabalho Social, Participação e & Acesso à Cidade e a Serviços \\
\hline Sociabilidade & Sociabilidade \\
\cline { 2 - 2 } & Participação \\
\cline { 2 - 2 } & Avaliação sobre o Trabalho Social \\
\hline \multirow{2}{*}{ Satisfação e Necessidades do Morador } & $\begin{array}{l}\text { Avaliação do Morador sobre Necessidades, Condiçóes } \\
\text { de Moradia e Relaçóes Sociais }\end{array}$ \\
\hline
\end{tabular}

Fonte: Miranda, 2018.

No Quadro 3 estão as quantidades de questionários calculados e aplicados em cada um dos empreendimentos. Aplicou-se, na maioria dos casos, um número maior de questionários, ultrapassando a amostra calculada e, assim, conferindo mais segurança na obtenção de dados. A exceçáo foi o caso do Condomínio Residencial Dona Lindú em Campina Grande, em decorrência de dificuldades de acesso aos condomínios.

Quadro 3 - Características dos Empreendimentos estudados

\begin{tabular}{l|c|c|c}
\hline $\begin{array}{l}\text { EMPREENDIMEN- } \\
\text { TOS ESTUDADOS }\end{array}$ & $\begin{array}{c}\text { No TOTAL DE UNI- } \\
\text { DADES }\end{array}$ & $\begin{array}{c}\text { QUESTIONÁRIOS } \\
\text { CALCULADOS }\end{array}$ & $\begin{array}{c}\text { QUESTIONÁRIOS } \\
\text { APLICADOS }\end{array}$ \\
\hline Morada dos Hibiscos & 224 & 54 & 58 \\
\hline Solar das Mangueiras & 165 & 50 & 68 \\
\hline $\begin{array}{l}\text { Major Veneziano I, II, } \\
\text { III e IV }\end{array}$ & 1984 & 69 & 80 \\
\hline $\begin{array}{l}\text { Dona Lindú I, II, III } \\
\text { e IV }\end{array}$ & 944 & 66 & 60 \\
\hline Vista da Serra I e II & 245 & 55 & 63 \\
\hline
\end{tabular}

Fonte: Miranda, 2018.

\section{O universo de estudo: Joáo Pessoa, Campina Grande e Patos}

No município de João Pessoa, foram estudados empreendimentos do PMCMV na Modalidade Entidades. O objetivo foi confrontar com os 
demais casos estudados e averiguar se o modelo de empreendimento nessa modalidade, produzido por associaçóes, cooperativas etc., apresentaria diferenças quanto à inserção e às condições urbanísticas, arquitetônicas e construtivas. Os empreendimentos selecionados foram os condomínios Morada dos Hibiscos e Solar das Mangueiras, realizados por uma cooperativa, com tipos habitacionais diferentes; o primeiro, integrado por edifícios multifamiliares e o segundo, contando com unidades térreas unifamiliares. No Caso de Campina Grande foram analisados os conjuntos residenciais Dona Lindú I, II, III e IV e o Major Veneziano I, II, III e IV, ambos compostos por condomínios integrados por edifícios multifamiliares verticalizados. Eram os maiores empreendimentos habitacionais entregues até o momento de seleção dos casos para a pesquisa. No município de Patos foram analisados os Residenciais Vista da Serra I e II, compostos por edificaçóes unifamiliares térreas independentes.

Cartograma 1 - Regióes Metropolitanas de João Pessoa, Campina Grande e Patos no Estado da Paraíba

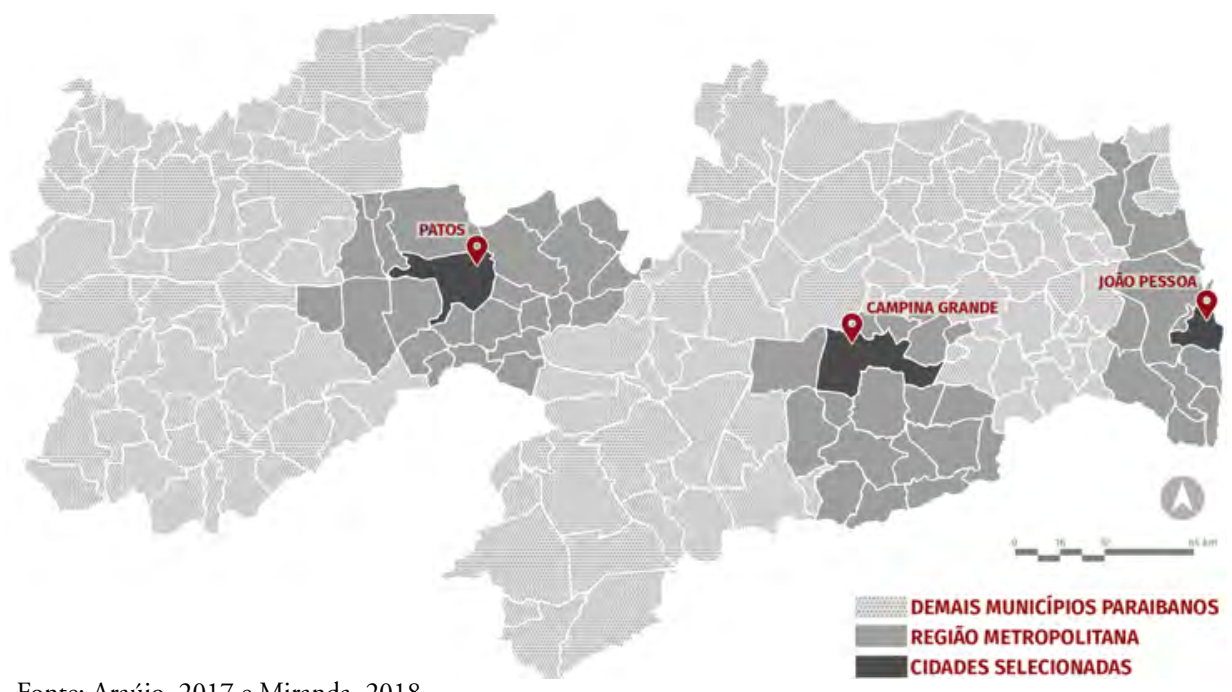

Fonte: Araújo, 2017 e Miranda, 2018. 
Cartograma 2 - Morada dos Hibiscos e Solar das Mangueiras em João Pessoa-PB

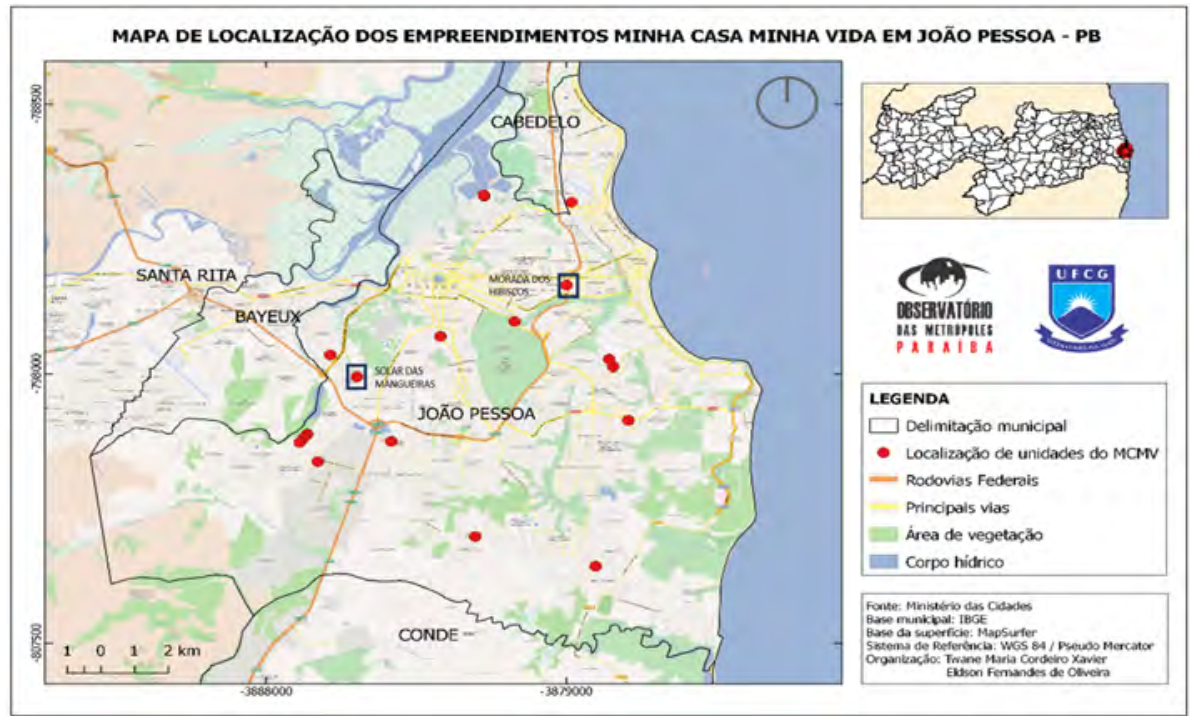

Fonte: Araújo, 2017 e Miranda, 2018.

Cartograma 3 - Residenciais Dona Lindú I, II, III e IV e Major Veneziano I, II, III e IV em Campina Grande-PB

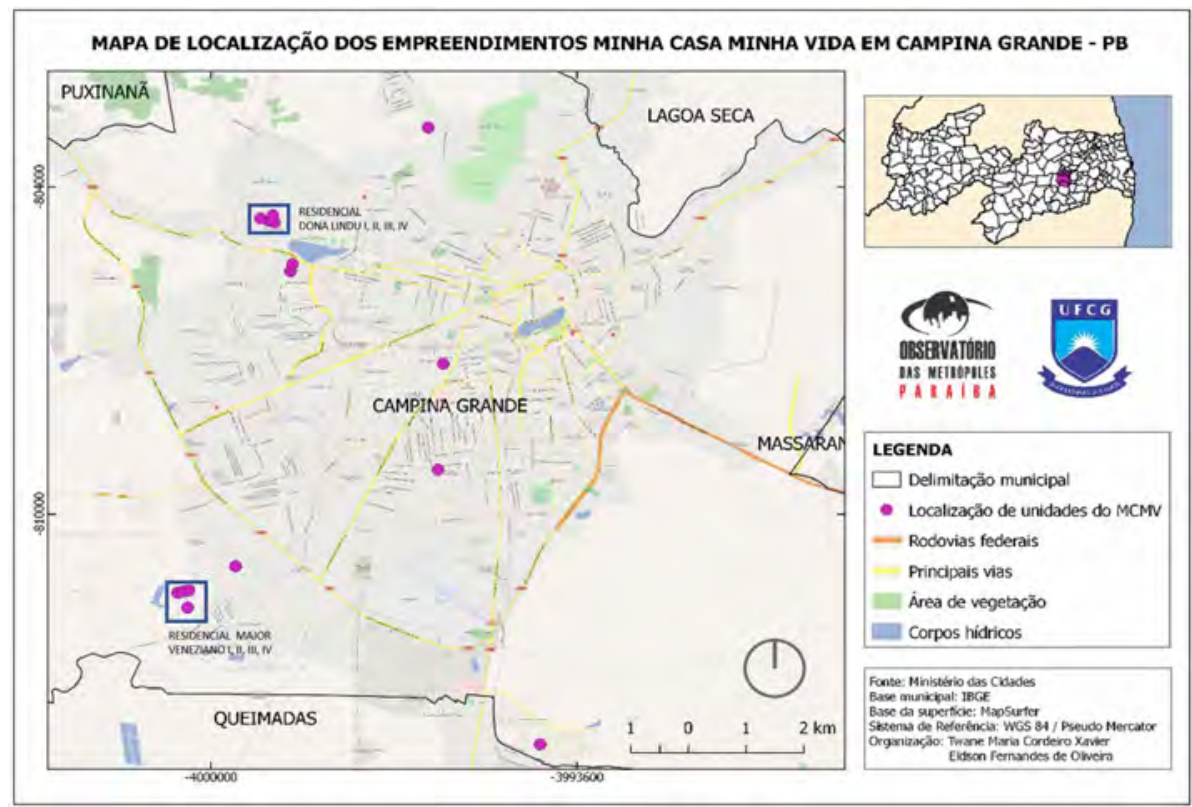

Fonte: Araújo, 2017 e Miranda, 2018. 
Cartograma 4 - Residenciais Vista da Serra I e II em Patos-PB

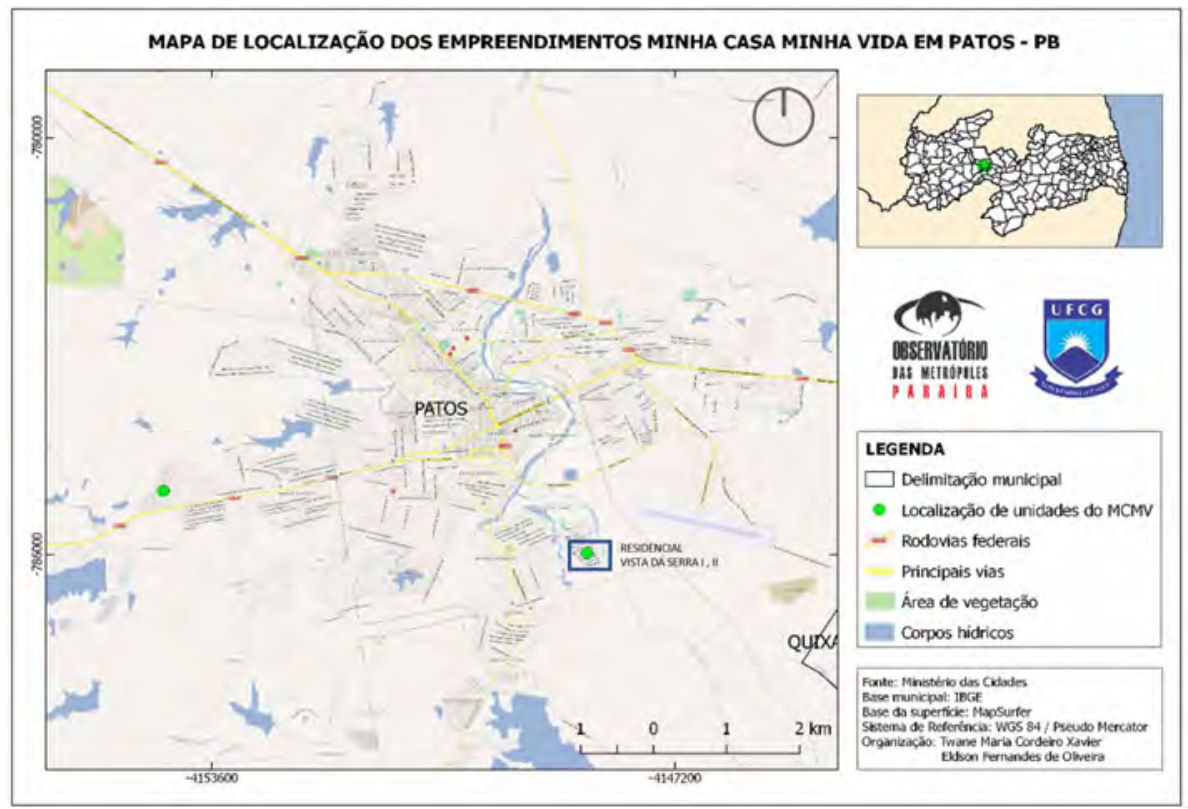

Fonte: Araújo, 2017 e Miranda, 2018.

Ferramenta de avaliação de inserção urbana: temas, indicadores parâmetros e qualificação

A Ferramenta é fruto de uma parceria entre o LabCidade (Laboratório Espaço Público e Cidade da Faculdade de Arquitetura e Urbanismo da USP) e o ITDP Brasil (Instituto de Políticas de Transporte e Desenvolvimento). ${ }^{22}$ No Quadro 4 constam os temas, indicadores, parâmetros e qualificação que foram utilizados na pesquisa, referenciados na Ferramenta, com parâmetros adaptados considerando as condições dos Municípios estudados.

2 A ferramenta foi desenvolvida como produto da pesquisa "Ferramentas para avaliação da inserção urbana dos empreendimentos do MCMV", coordenada por Raquel Rolnik e realizada com recursos do CNPq (com recursos da Chamada MCTI/CNPq/ MCIDADES no 11/2012) e da Ford Foundation. 
Quadro 4 - Ferramenta de Avaliação de Inserção Urbana

TEMA 01: TRANSPORTE

\begin{tabular}{|c|c|c|}
\hline Indicadores & Parâmetros & Qualificação \\
\hline $\begin{array}{l}\text { 1. OPÇÓES DE } \\
\text { TRANSPORTE }\end{array}$ & \multirow{3}{*}{$\begin{array}{l}\text { Quantidade de itinerários di- } \\
\text { ferentes realizados por uma ou } \\
\text { mais linhas de transporte públi- } \\
\text { co, que podem ser acessadas em } \\
\text { pontos de ônibus localizados no } \\
\text { entorno do empreendimento. }\end{array}$} & $\begin{array}{l}\text { Boa - } 4 \text { ou mais itinerários dife- } \\
\text { rentes }\end{array}$ \\
\hline \multirow{2}{*}{$\begin{array}{l}\text { Avaliar se o local onde será } \\
\text { construído o empreendimento } \\
\text { é bem servido de opçóes de } \\
\text { transporte público e diversidade } \\
\text { de itinerários. }\end{array}$} & & $\begin{array}{l}\text { Aceitável - Pelo menos } 3 \text { itinerá- } \\
\text { rios diferentes }\end{array}$ \\
\hline & & $\begin{array}{l}\text { Insuficiente - } 2 \text { ou menos itinerá- } \\
\text { rios diferentes }\end{array}$ \\
\hline $\begin{array}{l}\text { 2. FREQUENCIA DO } \\
\text { TRANSPORTE }\end{array}$ & \multirow{3}{*}{$\begin{array}{l}\text { Frequência e período de opera- } \\
\text { ção das linhas de transporte pú- } \\
\text { blico identificadas no Indicador } \\
1 \text { - Opçóes de Transporte duran- } \\
\text { te os dias úteis. }\end{array}$} & $\begin{array}{l}\text { Boa - Até } 10 \text { min., com período } \\
\text { de operaçáo } 24 \text { horas }\end{array}$ \\
\hline \multirow{2}{*}{$\begin{array}{l}\text { Avaliar o serviço das opçóes de } \\
\text { transporte público existentes, } \\
\text { observando a presença de frequ- } \\
\text { ência regular e tempos de espera } \\
\text { aceitáveis. }\end{array}$} & & $\begin{array}{l}\text { Aceitável - } 11 \text { a } 20 \text { min., com pe- } \\
\text { ríodo de operaçáo } 17 \text { horas }\end{array}$ \\
\hline & & $\begin{array}{l}\text { Insuficiente - Acima de } 20 \text { min., } \\
\text { com período de operaçáo inferior } \\
\text { a } 17 \text { horas }\end{array}$ \\
\hline
\end{tabular}

TEMA 02: OFERTA DE EQUIPAMENTOS, COMÉRCIO E SERVIÇOS

\begin{tabular}{|c|c|c|}
\hline Indicadores & Parâmetros & Qualificação \\
\hline 3. USOS COTIDIANOS ${ }^{33}$ & \multirow{3}{*}{$\begin{array}{l}\text { Existência de todos os Usos Obri- } \\
\text { gatórios e uma porcentagem dos } \\
\text { Usos Complementares, acessíveis } \\
\text { em } 15 \text { minutos }(1000 \mathrm{~m}) \text { a pé; }\end{array}$} & $\begin{array}{l}\text { Boa - Todos os usos obrigató- } \\
\text { rios e complementares }\end{array}$ \\
\hline \multirow{2}{*}{$\begin{array}{l}\text { Avaliar a diversidade de equi- } \\
\text { pamentos, comércio e serviços } \\
\text { próximos que impliquem } \\
\text { deslocamentos diários com } \\
\text { crianças ou pequenas compras. }\end{array}$} & & $\begin{array}{l}\text { Aceitável - Todos os usos obri- } \\
\text { gatórios e pelo menos } 4 \text { com- } \\
\text { plementares }\end{array}$ \\
\hline & & $\begin{array}{l}\text { Insuficiente - Não há todos os } \\
\text { usos obrigatório e/ou menos de } \\
4 \text { complementares }\end{array}$ \\
\hline 4. USOS EVENTUAIS ${ }^{44}$ & \multirow{3}{*}{$\begin{array}{l}\text { Existência de todos os Usos } \\
\text { Obrigatórios e uma porcentagem } \\
\text { dos Usos Complementares, aces- } \\
\text { síveis em } 20 \text { minutos (1400m) a } \\
\text { pé ou } 30 \text { minutos com transporte } \\
\text { público. }\end{array}$} & $\begin{array}{l}\text { Boa - Todos os usos obrigatórios } \\
\text { e complementares }\end{array}$ \\
\hline \multirow{2}{*}{$\begin{array}{l}\text { Avaliar a oferta de equipamen- } \\
\text { tos, comércios e serviços de usos } \\
\text { eventuais ou que possam ser } \\
\text { mais demorados para usuários } \\
\text { adultos. }\end{array}$} & & $\begin{array}{l}\text { Aceitável - Todos os usos obri- } \\
\text { gatórios e pelo menos } 7 \text { com- } \\
\text { plementares }\end{array}$ \\
\hline & & $\begin{array}{l}\text { Insuficiente - Não há todos os } \\
\text { usos obrigatório e/ou menos de } \\
7 \text { complementares }\end{array}$ \\
\hline
\end{tabular}

${ }^{3}$ Usos Obrigatórios: Creche pública, escola pública de ensino infantil, área de lazer e mercadinho. Usos Complementares: açougue, padaria, farmácia, restaurantes, salão de beleza, academia, lotérica, assistência técnica e loja de materiais de construção.

${ }^{4}$ Usos Obrigatórios: Escola pública de ensino fundamental, médio e/ou técnico, UBS, farmácia, área para práticas esportivas, supermercado, lotérica. Usos Complementares: 


\begin{tabular}{|c|c|c|}
\hline 5. USOS ESPORÁDICOS 5 & \multirow{3}{*}{$\begin{array}{l}\text { Existência de todos os Usos } \\
\text { Obrigatórios e uma porcentagem } \\
\text { dos Usos Complementares, aces- } \\
\text { síveis em } 1 \text { hora com transporte } \\
\text { público. }\end{array}$} & $\begin{array}{l}\text { Boa - Todos os usos obrigatórios } \\
\text { e complementares }\end{array}$ \\
\hline \multirow{2}{*}{$\begin{array}{l}\text { Avaliar a oferta de equipamen- } \\
\text { tos, comércios e serviços não } \\
\text { essenciais, mas que garantam } \\
\text { boa inserção urbana do empre- } \\
\text { endimento. }\end{array}$} & & $\begin{array}{l}\text { Aceitável - Todos os usos obri- } \\
\text { gatórios e pelo menos } 3 \text { comple- } \\
\text { mentares }\end{array}$ \\
\hline & & $\begin{array}{l}\text { Insuficiente - Não há todos os } \\
\text { usos obrigatórios e/ou menos de } \\
3 \text { complementares }\end{array}$ \\
\hline
\end{tabular}

TEMA 03: DESENHO E INTEGRAÇÃO URBANA

\begin{tabular}{|c|c|c|}
\hline Indicadores & Parâmetros & Qualificação \\
\hline $\begin{array}{l}\text { 6. RELAÇÃO COM } \\
\text { ENTORNO }\end{array}$ & \multirow{3}{*}{$\begin{array}{l}\text { Porcentagem do perímetro, ou dos } \\
\text { empreendimentos contíguos, que } \\
\text { é adjacente ao entorno urbano. }\end{array}$} & Boa - 100\% \\
\hline \multirow{2}{*}{$\begin{array}{l}\text { Avaliar a relaçáo do empreendi- } \\
\text { mento com o entorno imediato. }\end{array}$} & & Aceitável $-40 \%$ ou mais \\
\hline & & Insuficiente - Menos de 40\% \\
\hline $\begin{array}{l}\text { 7. TAMANHO DAS } \\
\text { QUADRAS }\end{array}$ & \multirow{3}{*}{$\begin{array}{l}\text { Média do perímetro das qua- } \\
\text { dras do empreendimento, ou } \\
\text { conjunto de empreendimentos } \\
\text { contíguos, e de todas as quadras } \\
\text { imediatamente adjacentes a eles. }\end{array}$} & Boa - Até 500 metros \\
\hline \multirow{2}{*}{$\begin{array}{l}\text { Avaliar o padrão do desenho } \\
\text { urbano, observando forma e } \\
\text { dimensóes das quadras dentro e } \\
\text { adjacentes aos empreendimentos } \\
\text { produzem caminhos variados, } \\
\text { curtos e diretos. }\end{array}$} & & Aceitável - De 500 a 800 metros \\
\hline & & $\begin{array}{l}\text { Insuficiente - Acima de } 800 \text { me- } \\
\text { tros }\end{array}$ \\
\hline $\begin{array}{l}\text { 8. ABERTURAS PARA O } \\
\text { ESPAÇO PÚBLICO }\end{array}$ & \multirow{3}{*}{$\begin{array}{l}\text { Número de acessos de pedestres } \\
\text { para cada } 100 \text { metros de divisas } \\
\text { entre as áreas privadas do empre- } \\
\text { endimento e as vias públicas de } \\
\text { circulação de pedestres. }\end{array}$} & Boa - 4 ou mais \\
\hline \multirow{2}{*}{$\begin{array}{l}\text { Avaliar a interface com o espaço } \\
\text { público, ou seja, as relaçóes entre } \\
\text { espaço público e espaços privados } \\
\text { produzidos pelo empreendimento. }\end{array}$} & & Aceitável - 2 ou mais \\
\hline & & Insuficiente - Menos de 2 \\
\hline $\begin{array}{l}\text { 9. REDE DE CIRCULAÇÃO } \\
\text { DE PEDESTRES }^{6}\end{array}$ & \multirow{3}{*}{$\begin{array}{l}\text { Caminhos até pontos de ônibus, } \\
\text { sistema de transporte e usos coti- } \\
\text { dianos sejam completos. }\end{array}$} & $\begin{array}{l}\text { Boa - Todos os elementos com- } \\
\text { pletos ao transporte e usos coti- } \\
\text { dianos }\end{array}$ \\
\hline \multirow{2}{*}{$\begin{array}{l}\text { Avaliar se os caminhos de } \\
\text { pedestres obedecem a padróes } \\
\text { mínimos de acessibilidade e } \\
\text { qualidade. }\end{array}$} & & $\begin{array}{l}\text { Aceitável - Todos os elementos } \\
\text { completos ao transporte }\end{array}$ \\
\hline & & $\begin{array}{l}\text { Insuficiente - Trechos não com- } \\
\text { pletos }\end{array}$ \\
\hline
\end{tabular}

Fonte: Miranda (2018) a partir da Ferramenta de Avaliação de Inserção Urbana (Rolnik, 2014).

Instituição de ensino superior, CRAS, biblioteca pública, delegacia, centro médico, correios, lojas, restaurantes, banco, escritórios, livraria, assistência técnica, escolas de formação complementar.

5 Usos Obrigatórios: Hospital público, centro administrativo, instituição de ensino superior, banco. Usos Complementares: Cinemas, parques, teatro, museu, hipermercado, cartório.

6 A rede de circulação pedestres é composta e completa quando (i) Todo o espaço de circulação de pedestres (calçadas, calçadóes, travessias) e pontos de acesso ao transpor- 
No caso do Município de João Pessoa, há particularidades nas bases de dados sobre a disponibilidade e oferta de serviço de transporte. Foram usadas as informações do site "Ônibus JP” (João Pessoa, 2017). Nele é possível localizar os pontos de ônibus e os itinerários da cidade. Também é possível selecionar os lugares de partida e chegada e é disponibilizado o percurso tanto a pé, até a parada do transporte público mais próximo, quanto as rotas que se deve pegar para chegar ao destino. Entretanto, não é possível verificar o tempo do trajeto, por isso, para a aferiçáo do tempo do percurso até os usos considerados, recorreu-se ao Google Maps. Para a capital, não existe o recurso de transporte público, estando disponível apenas outros modais. Então, marcou-se o trajeto da rota do ônibus no mapa da segunda base, com o tempo de duração até os usos com o carro, mesmo tomando em conta que os tempos não são exatos em função das paradas durante o caminho, não consideradas na marcação do tempo com o carro. Foi considerado o tempo encontrado, mas sabendo que pode haver variação.

A partir da ferramenta para avaliação da inserção urbana, adaptada aos municípios da Paraíba, foram avaliadas as condiçôes de inserção urbana dos empreendimentos selecionados para o estudo. Em função do grande número de variáveis contidas na ferramenta e da limitação da quantidade de páginas disponíveis para apresentação do trabalho, foram selecionadas apenas algumas variáveis para apresentação no corpo do artigo. A análise completa se encontra disponível no relatório Empreendimentos Habitacionais em Espaços Periféricos: Desafios para o Planejamento Territorial Integrado (Miranda, 2018).

\section{A inserção Urbana de empreendimentos do Programa Minha Casa Minha Vida em João Pessoa, Campina Grande e Patos na Paraíba}

Até o ano de 2015, o Programa Minha Casa Minha Vida destinou 1/3 da sua produçáo nas duas primeiras fases para o Nordeste, mas o estado da Paraíba foi um dos que menos contrataram pelo PMCMV. Dos 223 municípios que compóem o estado, 219 receberam empreendimentos do PMCMV. Segundo os dados do Ministério das Cidades (2015), foram os Municípios de João Pessoa e Campina Grande que concentraram o maior número de

te são dedicados aos pedestres, desobstruídos, seguros e contenham abrigo; (ii) Rede de iluminação cobrem toda a extensão da circulação à noite e; (iii) a arborização e o sombreamento nos caminhos não obstruem a circulação do pedestre. 
empreendimentos e de unidades habitacionais promovidos pelo PMCMV na Faixa 1, com quase $80 \%$ dos empreendimentos executados no estado.

Em Campina Grande, foram construídos os maiores empreendimento executados na Paraíba. Os condomínios se avizinham sucessivamente, conformando conjuntos de três ou mais empreendimentos, a exemplo do Dona Lindú (I, II, III, IV), Major Veneziano (I, II, III, IV) e Aluízio Campos. Esse perfil deve-se à maior disponibilidade de terrenos nas bordas urbanas. Patos e Maranguape se destacam com dois empreendimentos realizados no período.

\section{João Pessoa: a inserção urbana dos residenciais Solar das Mangueiras e Morada dos Hibiscos}

Os empreendimentos selecionados em João Pessoa escolhidos para a análise - Solar das Mangueiras e Morada dos Hibiscos - foram promovidos com recursos do PMCMV na modalidade Entidades. Embora estejam localizados em áreas periféricas, esses empreendimentos diferenciam-se dos demais estudados na Paraíba por suas condiçóes de inserção urbana e portes menores.

Para o Tema 1, que se refere ao transporte, foram levantados os pontos de transporte público acessíveis em $1 \mathrm{~km}$ de distância do centro geométrico, levando em conta que este é considerado a partir da intersecção das poligonais traçadas pelas extremidades de cada empreendimento (Cartogramas 5 e 6). Ambos os residenciais são atendidos por apenas uma linha de ônibus (indicador 1). Portanto, os moradores desses conjuntos têm que buscar alternativas em integraçóes ou outros pontos de ônibus para poderem acessar outros itinerários e destinos. Os moradores relataram que os tempos de espera dos ônibus são longos, variando de $30 \mathrm{~min}$ a 1 hora, apesar das partidas dos ônibus estarem previstas para ocorrer de 30 em 30 minutos (indicador 2). Essas condiçóes conferem aos empreendimentos estudados a qualificação de insuficiente considerando os dois indicadores, opçóes (1) e frequência (2) do transporte.

Nos dois casos de João Pessoa, o transporte público não era o meio de deslocamento mais utilizado. No residencial Morada dos Hibiscos, das 58 famílias entrevistadas, 45 utilizavam veículos individuais próprios, moto e/ou carro. No Condomínio Residencial Solar das Mangueiras, 53 das 68 famílias que responderam aos questionários também utilizavam veículos individuais próprios, prioritariamente, para os deslocamentos diários. 
Cartograma 5 - Unidade central e pontos de ônibus - Morada dos Hibiscos, João Pessoa

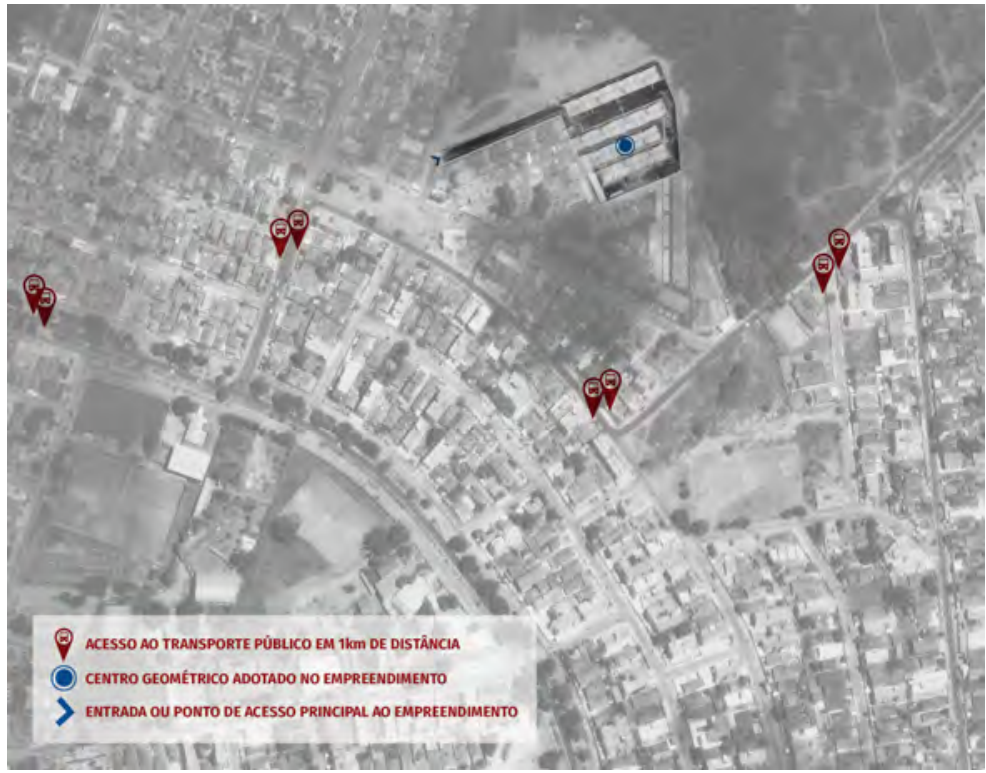

Fonte: Base Google Earth, Base Google Earth, Araújo, 2017 e Miranda, 2018.

Cartograma 6 - Unidade central e pontos de ônibus - Solar das Mangueiras, João Pessoa

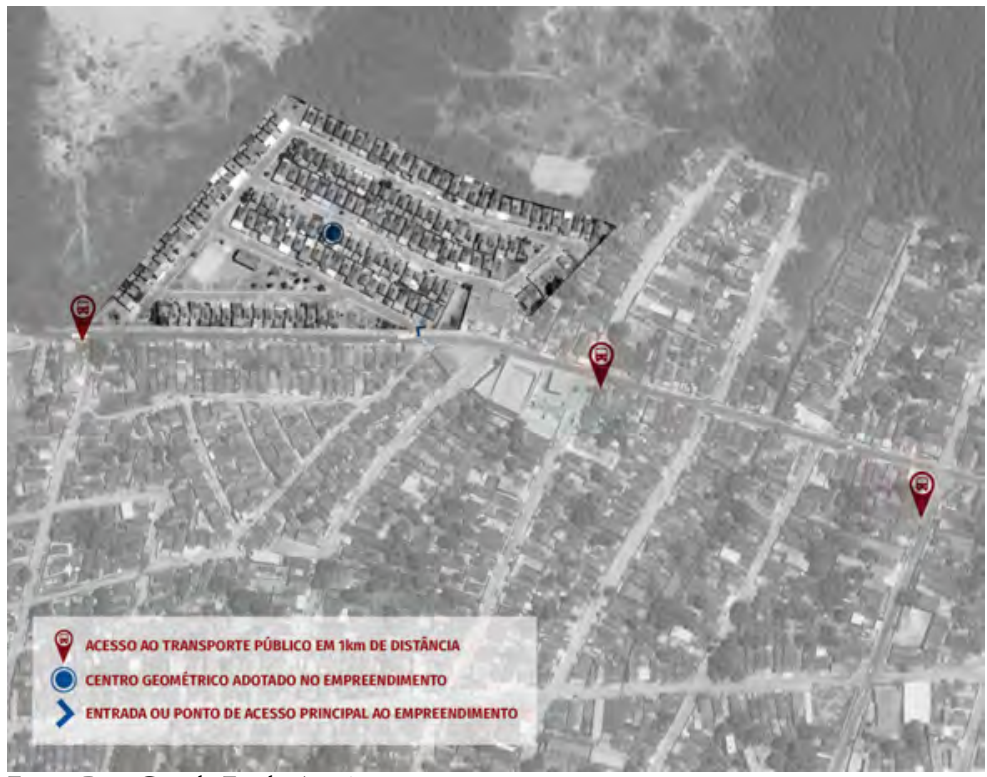

Fonte: Base Google Earth, Araújo, 2017. 
O Tema 2, relativo à oferta de equipamentos no entorno dos conjuntos, para os indicadores que avaliam o entorno de $1 \mathrm{~km}$ a $1,4 \mathrm{~km}$, os empreendimentos obtiveram a pior qualificação, Insuficiente, apesar de ser observado que a maioria dos usos está no raio de $1,4 \mathrm{~km}$ ou bem próximos dele. Os empreendimentos de João Pessoa, mesmo com insuficiências, apresentaram a maior diversidade de usos e equipamentos em seus entornos em comparação aos empreendimentos estudados nas demais cidades. O Solar das Mangueiras conta, em seu entorno, com 26 de 34 equipamentos essenciais e o Morada dos Hibiscos, com 25.

Para o indicador relativo a usos esporádicos, foram destacados apenas três usos obrigatórios e de mais facilidade de identificação na cidade: Hospitais Públicos, Centro Administrativo Público (Prefeitura) e Instituiçóes de Ensino Superior Públicas. A qualificação foi Aceitável, considerando que estes equipamentos estão acessíveis em 1 hora com transporte público.

No Tema 3, referente aos aspectos de desenho urbano, configurações métricas, qualitativas, físicas e formais dos empreendimentos, foram analisados: a relação com entorno (indicador 6); tamanho das quadras (7); Abertura para espaços públicos (8); e a Rede de circulação de pedestres. $\mathrm{O}$ indicador 6 é relativo à porcentagem de áreas limítrofes do conjunto habitacional que estão adjacentes a um entorno qualificado como efetivamente urbano. Os empreendimentos apresentam cerca de $47 \%$ do seu entorno conectado ao tecido urbano (Cartogramas 7 e 8), com o restante margeando Zonas de Preservação Ambiental.

Cartograma 7 - Relação com entorno 46.6\% - Morada dos Hibiscos, Joáo Pessoa

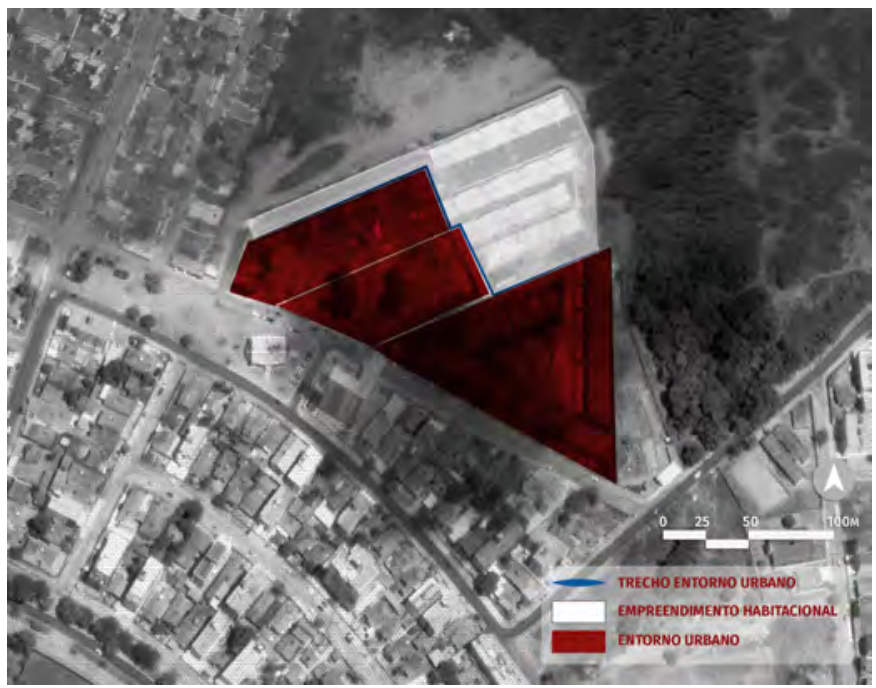

Fonte: Base Google Earth, Base Google Earth, Araújo, 2017. 
Cartograma 8 - Relação com entorno 47,13\% - Solar das Mangueiras, João Pessoa

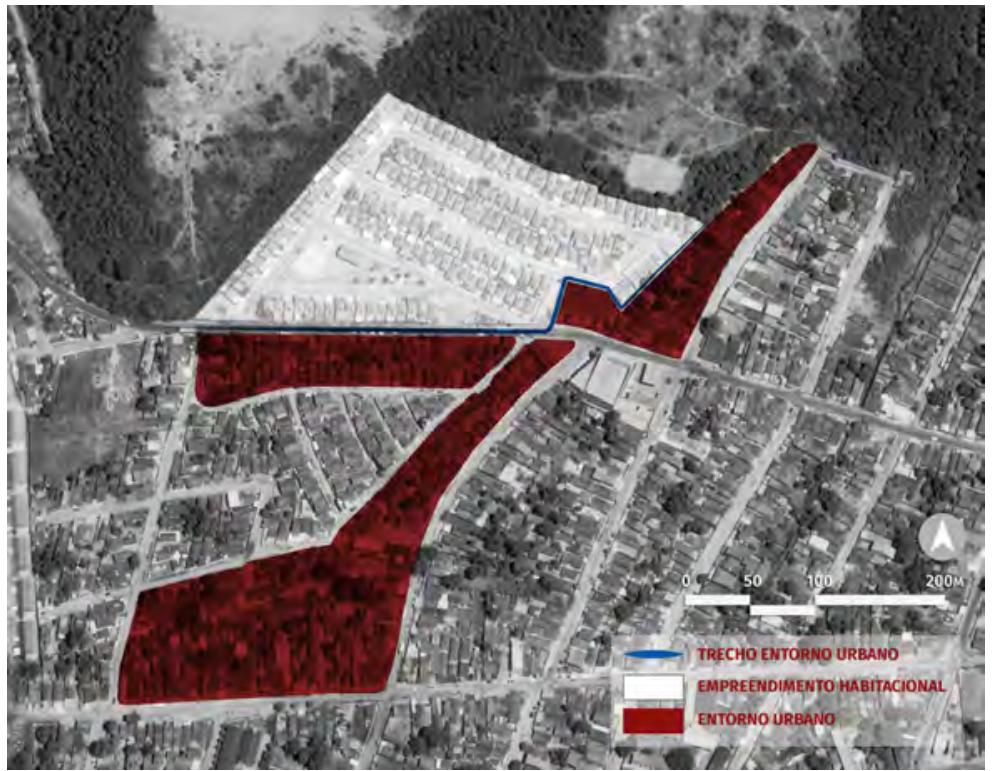

Fonte: Base Google Earth, Araújo, 2017.

Os tamanhos das quadras são avaliados buscando observar se as suas configuraçôes produzem caminhos variados que se integram facilmente à cidade. Em relação ao empreendimento Morada dos Hibiscos, que faz parte de uma quadra (Cartograma 9), foi considerada a quadra inteira para os parâmetros da Ferramenta e o resultado da qualificação foi Bom. O Solar das Mangueiras apresentou a qualificação Aceitável (Cartograma 10). 
Cartograma 9 - Tamanho das quadras 775m - Morada dos Hibiscos, Joáo Pessoa

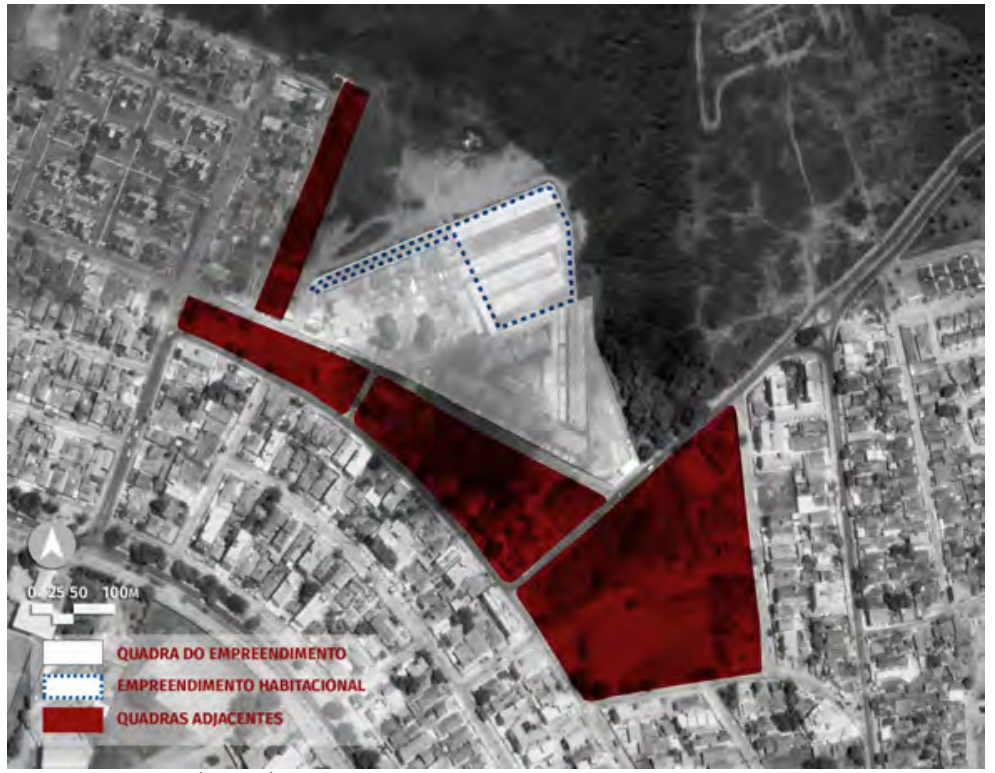

Fonte: Base Google Earth, Araújo, 2017.

Cartograma 10 - Tamanho das quadras 775m - Solar das Mangueiras, Joáo Pessoa.

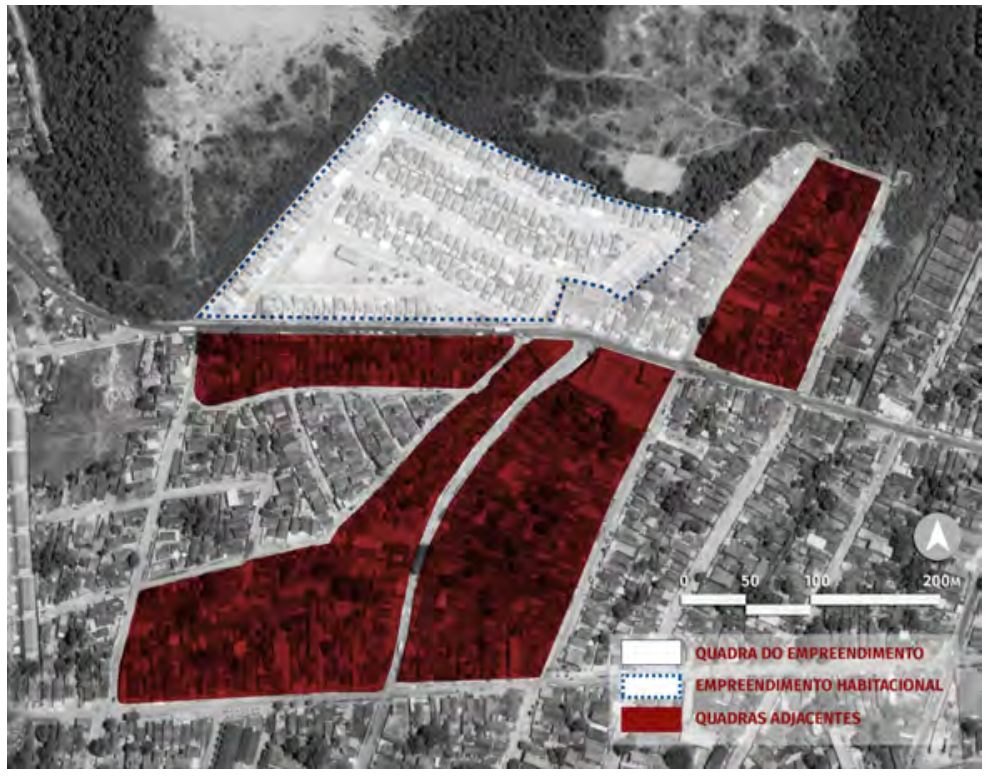

Fonte: Base Google Earth, Araújo, 2017. 
As aberturas para o espaço público (indicador 8) são aferidas a partir da verificação da quantidade de relaçôes ou divisas público/privado, a cada 100 metros, entre o conjunto habitacional e vias de circulação de pedestres pelos parâmetros da Ferramenta. Como o Solar das Mangueiras e o Morada dos Hibiscos são empreendimentos com uma única entrada, ambos tiveram a qualificação de Insuficiente.

O último indicador (9) da Ferramenta trabalhado avalia a qualidade e a acessibilidade dos caminhos internos e externos, das portas das unidades habitacionais em direção aos equipamentos e serviços do entorno. Foi possível perceber nos empreendimentos estudados, que a acessibilidade foi priorizada apenas para as entradas das unidades acessíveis. No Morada dos Hibiscos, as unidades acessíveis estão no início do conjunto. No Solar das Mangueiras, quando não há desnível, existe um degrau para a entrada da casa, interferindo na mobilidade para o acesso à casa. A qualificação para a rede de circulação de pedestres, a partir dos parâmetros da Ferramenta, foi Insuficiente.

\section{A inserção urbana dos Residenciais Dona Lindú I, II, III E IV e Major Veneziano I, II, III E IV em Campina Grande}

Na cidade de Campina Grande, oito conjuntos foram estudados no âmbito da pesquisa, integrantes dos Residenciais Dona Lindú I, II, III, IV, organizados como quatro condomínios, voltados à Faixa 2 do PMCMV, situados no Bairro Novo Bodocongó, a noroeste da cidade; e dos Residenciais Major Veneziano I, II III e IV, também como quatro condomínios para a Faixa 1, situados no Bairro Três Irmãs, localizado na Área de Expansão Urbana.

Para o Tema 1, foram analisadas a oferta e frequência do transporte disponíveis e acessíveis aos moradores dos residenciais em Campina Grande (indicadores 1 e 2). Os pontos de parada de ônibus ofertados pelo município que estão a $1 \mathrm{~km}$ da unidade central de cada conjunto. Foram verificados, também, quais os percursos podiam ser efetuados a partir dessas paradas e se as linhas de ônibus faziam trajetos diferentes (Cartogramas 11 e 12). 
Cartograma 11 - Unidade central e pontos de ônibus - Dona Lindú, Campina Grande

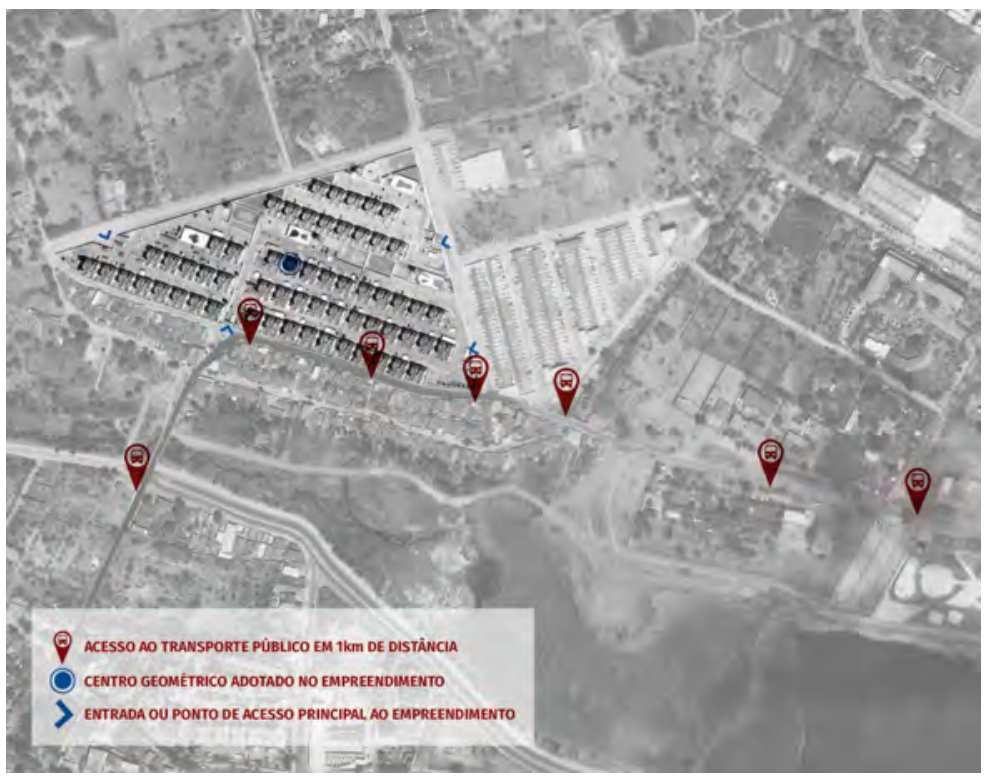

Fonte: Base Google Earth, Araújo, 2017.

Cartograma 12 - Unidade central e pontos de ônibus - Major Veneziano, Campina Grande

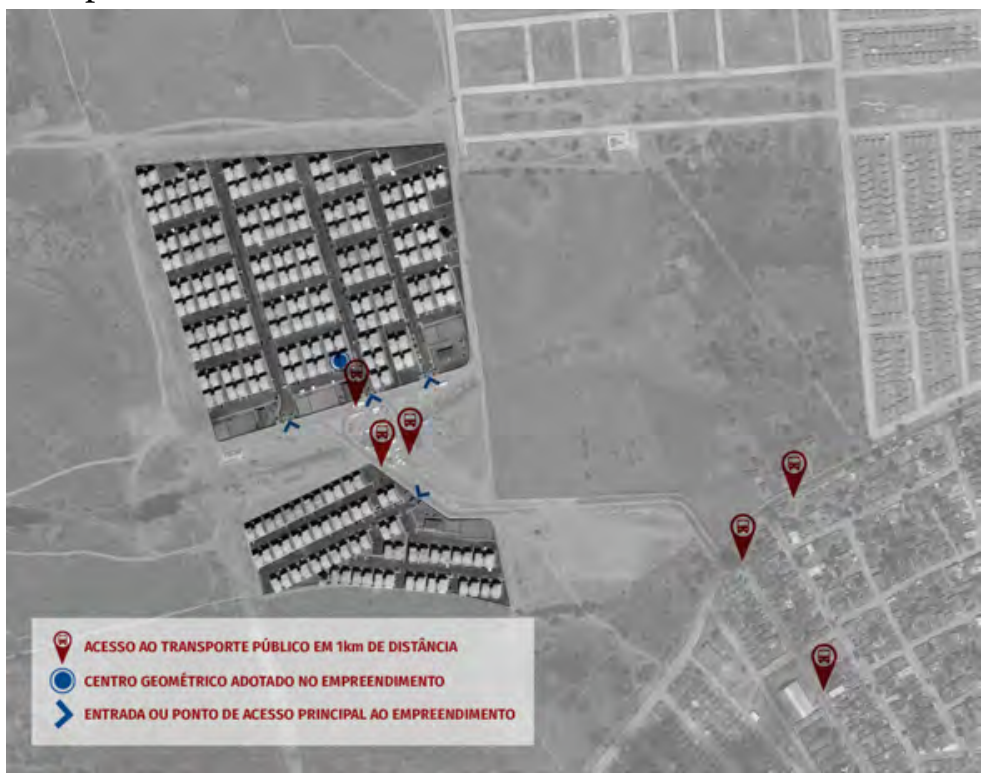

Fonte: Base Google Earth, Araújo, 2017. 
Para os Residenciais Dona Lindú, os percursos das 4 linhas acessadas pelos moradores ao percurso de $1 \mathrm{~km}$ têm distâncias inferiores a $2 \mathrm{~km}$ entre si quanto a seus itinerários, o que, pela Ferramenta, expressa uma única opção de rota, resultando em uma qualificação Insuficiente. Em relação aos Residenciais Major Veneziano I, II, III e IV, foram identificadas 2 linhas de ônibus como acessíveis ao percurso de $1 \mathrm{~km}$, com itinerários que distam apenas 900 metros. O resultado é qualificado, também, como Insuficiente.

Dos casos estudados, os moradores dos conjuntos de Campina Grande eram os que mais utilizavam o transporte público, por essa razão também havia mais reclamaçóes relacionadas aos tempos de espera e à quantidade de ônibus insuficiente para as linhas que vão até as áreas periféricas. Estes ônibus acabam percorrendo percursos mais longos até o destino ou ao terminal de integração para a conexão com outras linhas.

Em relação ao Tema 2, referente a equipamentos, para os indicadores 3 e 4, considerando as distâncias ou tempos estabelecidos como parâmetros, a qualificação para os dois conjuntos de Residenciais de Campina Grande foi considerada Insuficiente. Para o indicador 5, referente aos usos esporádicos, foram selecionados os três primeiros obrigatórios, Hospitais Públicos, Centro Administrativo Público (Prefeitura) e Instituiçóes de Ensino Superior Públicas. A partir dos tempos dos deslocamentos, foi constatado as qualificaçóes de Aceitável para o Dona Lindú, com deslocamentos em torno de 45 minutos para diferentes destinos e o Major Veneziano como Insuficiente, pois apresentou três deslocamentos com tempo superior a 1 hora.

A análise do Tema 3 foi realizada considerando os indicadores de 6 a 9 , estudando as métricas e configuraçóes urbanas dos conjuntos selecionados na cidade. As porcentagens de conexão com o entorno urbanizado (indicador 6) encontradas foram de 75\% e 0\%, para o Dona Lindú e o Major Veneziano, respectivamente (Cartogramas 13 e 14). A localização do Major Veneziano é periférica, em área que representa uma nova frente de expansão, com terrenos não ocupados na vizinhança. 
Cartograma 13: Relação com entorno 75\% - Dona Lindú, Campina Grande

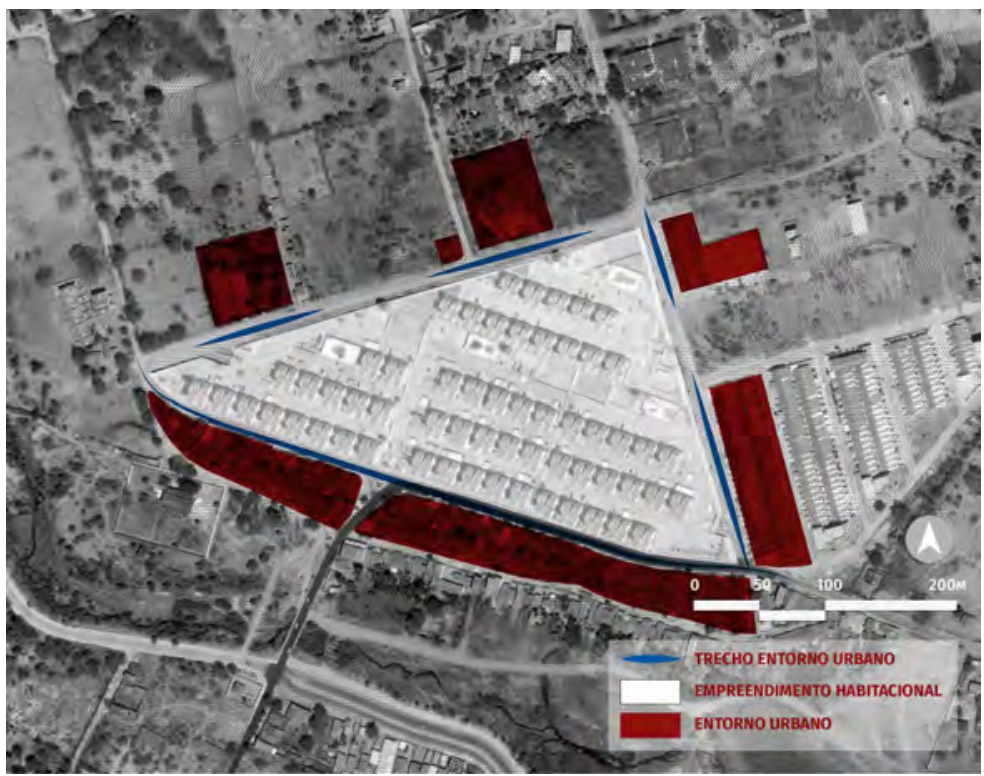

Fonte: Base Google Earth, Araújo, 2017.

Cartograma 14: Relação com entorno 0\% - Major Veneziano, Campina Grande

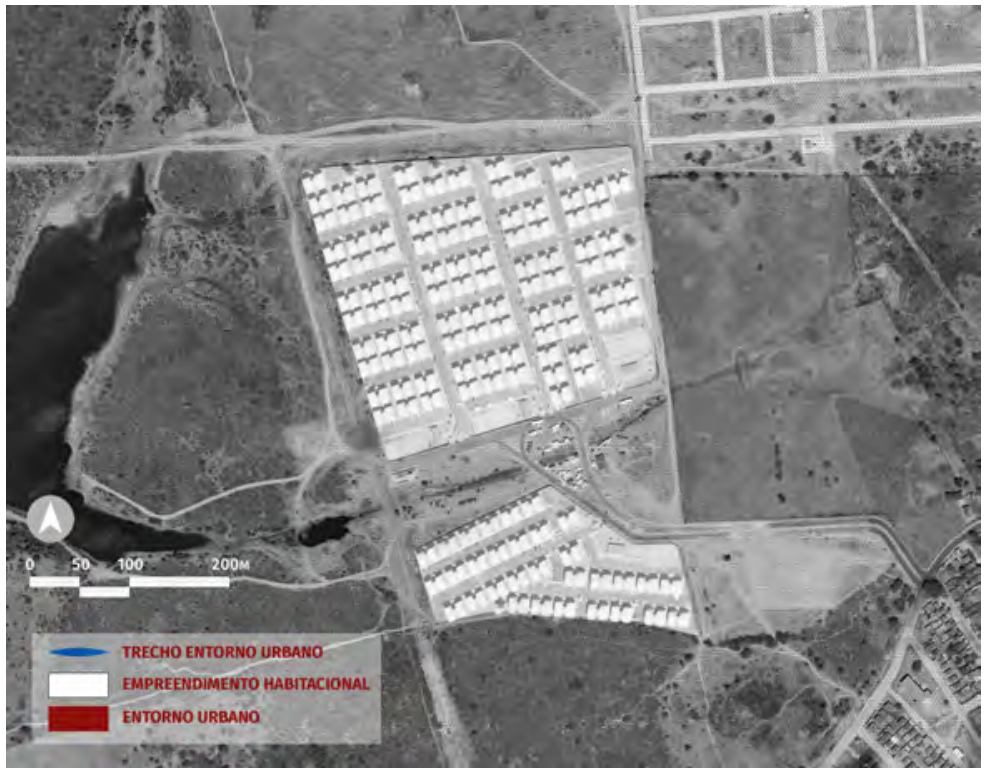

Fonte: Base Google Earth, Araújo, 2017. 
Os empreendimentos de Campina Grande são condomínios murados, com entradas e saídas únicas para conjunto. Devido ao grande porte e em decorrência da configuração urbanística, há caminhos mais longos para os moradores dos edifícios (indicador 7). Por essas razóes, considerando os parâmetros adotados na Ferramenta, suas qualificaçóes para o tamanho das quadras foram Insuficientes, em função de percursos superiores a 800 metros.

$\mathrm{Na}$ aferição das aberturas das divisas entre os espaços públicos (indicador 8), os empreendimentos de Campina Grande, a partir da Ferramenta, foram qualificados como Insuficientes, pois em cada residencial-condomínio há apenas uma abertura que dá acesso às vias públicas de circulação de pedestres.

A rede de circulação de pedestres (indicador 9) no interior no empreendimento e nos caminhos do entorno que levam aos equipamentos essenciais foram considerados como Insuficientes em função dos desníveis internos e problemas quanto à acessibilidade a espaços comuns, como a falta de rampa apesar da variação das dimensóes das calçadas, chegando a 20 centímetros de largura. Em relação ao transporte e ao caminho até ele, pôde ser observado que as condiçóes de acessibilidade são adequadas apenas em alguns trechos.

Os Residenciais Major Veneziano obtiveram a pior qualificação em todos os indicadores e os Residenciais Dona Lindú tiveram, em função da localização, resultados melhores, mas com apenas dois dos nove indicadores com qualificaçóes Aceitáveis, e nenhuma como Boa.

\section{A inserção urbana dos Residenciais Vista da Serra I E II em Patos}

A produção do espaço urbano em Patos vem se caracterizando, nessa última década, por uma diversidade de investimentos imobiliários que vêm gerando a expansão da malha urbana da cidade. Nessa área de transição rural-urbana, vem sendo realizados os empreendimentos habitacionais pelo PMCMV. Importante ressaltar que Campina Grande e Patos tiveram Leis Municipais que ampliaram os limites dos perímetros urbanos das cidades (Maia e Lucena, 2015). Os Residenciais Vista da Serra I e II em Patos, foram implantados de modo desarticulado da malha urbana, entre o Rio Espinharas e um braço desse rio. Outra especificidade desses empreendimentos é que são abertos, não se constituindo em condomínios murados, diferentes dos demais estudados no âmbito desta pesquisa. 
Em relação aos dois primeiros indicadores relativos (1 e 2) ao Tema Transporte, foram observadas questóes específicas relacionadas aos serviços urbanos. No período da pesquisa de campo na cidade, não havia transporte público. As linhas de coletivos na cidade pararam de funcionar em 2014 até o final de 2016, quando o serviço foi retomado. Eram somente quatro linhas que ligavam alguns bairros da cidade, com poucos ônibus circulando. Apenas uma linha atendia ao bairro (Araújo, 2017). Os moradores foram questionados sobre os deslocamentos ao trabalho e ao estudo e os três meios mais utilizados foram a motocicleta, a pé e a bicicleta.

A partir dos levantamentos para o Tema 2, foram identificados equipamentos, serviços e pontos de comércio, e detectados 18 dos 34 usos relacionados pela Ferramenta de Inserção urbana, sendo a qualificação considerada como Insuficiente. Em Patos, as percepçôes dos moradores em relação às distâncias não corresponderam às reais extensões. Estas percepçóes podem estar associadas às dificuldades para deslocamento em decorrência da precariedade das vias que dáo acesso aos equipamentos e aos empreendimentos de serviços e comerciais, com ruas sem calçamento ou deterioradas por falta de manutenção.

As análises dos usos esporádicos foram realizadas a partir da identificação dos três primeiros usos obrigatórios do indicador. Para os Residenciais Vista da Serra I e II, quando as visitas de campo foram feitas, não havia transporte público disponível e os deslocamentos eram realizados a partir de outros modais, como a bicicleta, o carro, a motocicleta e a pé, todos como modos individuais. Os resultados quanto ao tempo de deslocamento foram, então, aferidos da mesma forma dos casos estudados nas outras cidades e a qualificação foi Insuficiente.

Para os últimos indicadores, do Tema 3, relativo ao desenho e integração urbana, os casos de Patos foram os que obtiveram melhor qualificação em dois dos quatro indicadores, apesar de ter obtido um dos piores resultados para o indicador 6 , a relaçáo com o entorno. $\mathrm{Na}$ Cartograma 15, está demarcada linha que representa a porcentagem do perímetro dos empreendimentos selecionados na cidade que são adjacentes ao entorno urbanizado. Os residenciais tiveram o segundo pior resultado, com apenas $24,05 \%$ conectado aos espaços parcelados e efetivamente urbanos, por se localizarem em novas frentes de expansão. 
Cartograma 15 - Relação com entorno 24.05\% - Vista da Serra, Patos

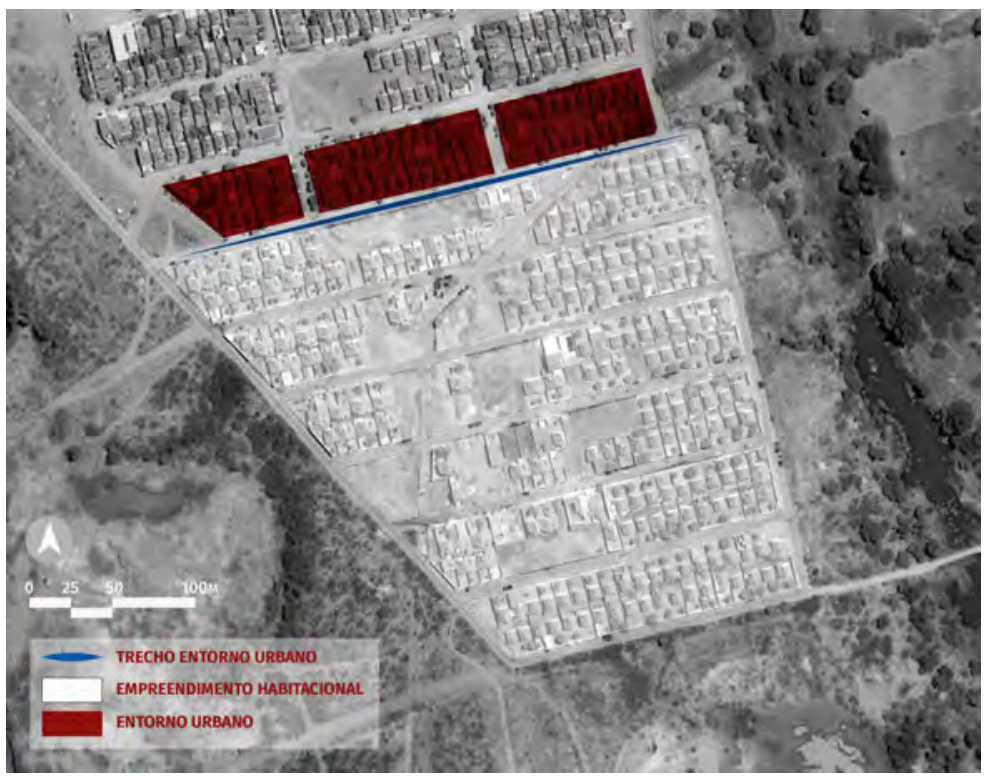

Fonte: Base Google Earth, Araújo, 2017.

Nos dois indicadores, Tamanho da Quadra (7) e Aberturas para o Espaço Público (8), os Residenciais Vista da Serra I e II receberam, a partir das suas características, as melhores qualificaçóes dos empreendimentos estudados. Os Residenciais Vista da Serra I e II obtiveram a média de 368,20 metros por quadra, sendo a melhor dos empreendimentos do PMCMV estudados na Paraíba.

Para o indicador 8, as aberturas das unidades habitacionais foram aferidas em sua totalidade, visto que os empreendimentos são abertos e cada conexão público/privado é considerada pela ferramenta. Assim, eles foram os únicos dos estudados na Paraíba que receberam a qualificação Boa. Esses indicadores podem ser identificados nas Cartogramas 16 e 17.

Sobre a rede de circulação dos pedestres, indicador 9, foi possível observar que as empresas e projetistas desses empreendimentos não priorizaram a acessibilidade nos casos dos Residenciais Vista da Serra I e II, em Patos. Apesar de ser apontado que, no projeto original, as calçadas, por exemplo, seriam desobstruídas, houve alteraçóes dos níveis das calçadas promovidas pelos moradores, conferindo obstáculos na acessibilidade e nos deslocamentos dos pedestres. Além disso, problemas de deterioração dos pavimentos das calçadas, dificuldades de acesso a unidade (desníveis) 
e a falta de pavimentação nas ruas de acesso ao residencial, resultaram na qualificação Insuficiente.

Cartograma 16 -Tamanho das quadras 368.20m - Vista da Serra, Patos

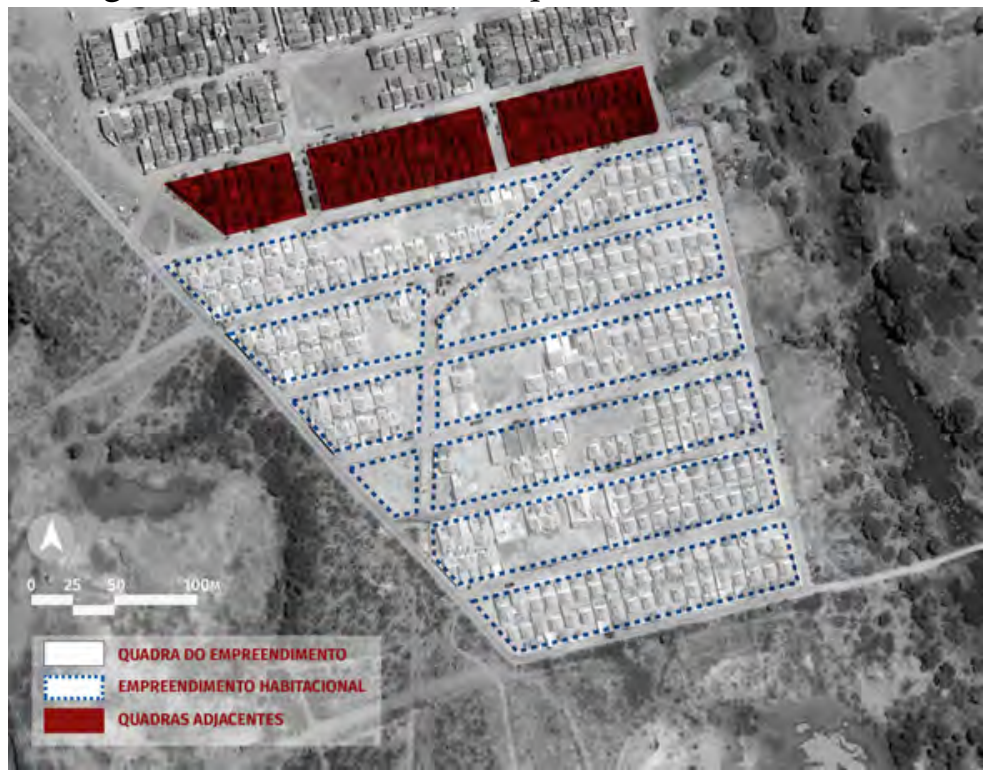

Fonte: Base Google Earth, Araújo, 2017.

Cartograma 17: Aberturas para o espaço público 6.65 - Vista da Serra, Patos

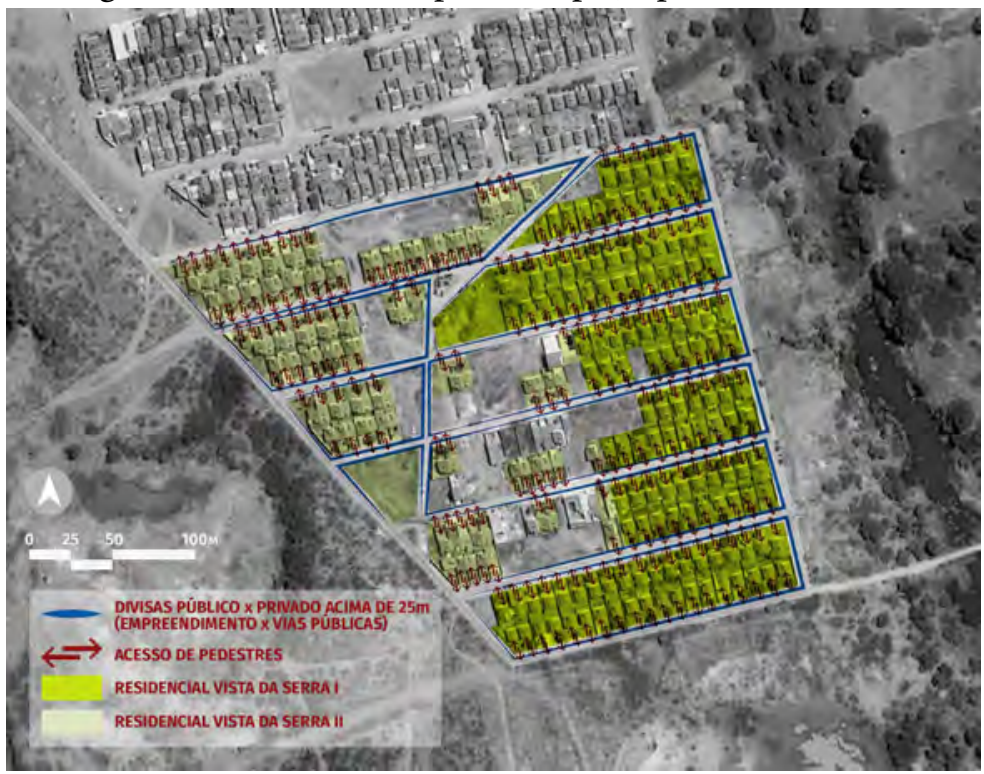

Fonte: Base Google Earth, Araújo, 2017. 


\section{Consideraçóes finais}

A pesquisa possibilitou a sistematização e análise de informações e observaçóes sobre os empreendimentos habitacionais promovidos no âmbito do PMCMV para o estado da Paraíba. Embora existam inúmeros estudos sobre o programa, poucos enfocaram as características dos espaços intermediários nordestinos. No caso paraibano, foi necessário propor adaptaçóes para diminuir constrangimentos metodológicos decorrentes das cidades estudadas, considerando a relação entre as dinâmicas e as dimensóes da mancha urbana, diferentes das encontradas na maioria das cidades que tiveram empreendimentos do PMCMV estudados. A partir de uma abordagem interdisciplinar, a pesquisa demonstra que há grande necessidade de articulaçáo, entre as várias dimensóes espaciais das políticas urbanas e dessas com os respectivos instrumentos de planejamento e gestão. Dessa forma, o estudo poderá contribuir para orientar a elaboração de planos, programas e políticas públicas que influenciem e regulem a produção do espaço para promover maior urbanidade e garantir uma inserção mais adequada e justa das habitaçóes de interesse social na cidade.

São diversas as dificuldades para a implementação de políticas públicas federais, geralmente pouco flexíveis à diversidade e às especificidades dos municípios brasileiros. Mais especificamente, no caso do PMCMV, importante para atender as famílias com baixíssima renda, não se pode deixar de reconhecer que o programa fomentou, em muitas cidades, uma urbanizaçáo periférica, pouco diversificada e pouco inclusiva. Em relação aos empreendimentos estudados na Paraíba nesta pesquisa, não foi diferente.

A pesquisa contribuiu, também, para evidenciar que houve pouca articulação entre os instrumentos de planejamento, como os Planos Diretores, os Planos de Habitação, Saneamento e a alocação dos empreendimentos. Ficou claro que a regulaçáo dos processos de ocupação do solo está principalmente pavimentada em estratégias para viabilizar as principais dinâmicas promovidas pelo capital. Nessa perspectiva, a pesquisa serve como referência aos processos de planejamento territorial, principalmente para a implantação adequada de conjuntos habitacionais de interesse social, seja no âmbito governamental ou não governamental, permitindo definir estratégias para alcançar um desenvolvimento socioespacial mais equilibrado e inclusivo. 


\section{Referências}

ABNT ASSOCIAÇÃO BRASILEIRA DE NORMAS TÉCNICAS. NBR 9050: Acessibilidade a edificaçóes, mobiliário espaços e equipamentos urbanos. Rio de Janeiro. 2004.

ARAUJO, J. P. Inserção Urbana Habitacional: Possibilidades e Limites na Avaliação do Programa Minha Casa Minha Vida (PMCMV) em Cidades Médias da Paraíba. (Trabalho de Conclusão de Curso). Campina Grande: Universidade Federal de Campina Grande, 2017.

BRASIL. "Lei no 12.424, de 16 de junho de 2011". Presidência da República - Casa Civil. Disponível em: http:/www.planalto.gov.br/ccivil_03/_ato2011-2014/2011/lei/11242 4.htm. Acesso em: 20 ago. 2016.

CAMPINA GRANDE. Gerência de Operação e Fiscalização de Transportes, Central Integrada de Operação e Monitoramento de Ônibus, 2017. Disponível em: http://www.ciomcg.com. br/linhas-e-rotas.html. Acesso em: 25 jul. 2017.

CARDOSO, A. L. e DENALDI, R. Urbanização de Favelas no Brasil. Um balanço do PAC. Rio de Janeiro: Letra Capital, 2018.

et al. 22 anos de politica habitacional no Brasil: da euforia à crise. Rio de Janeiro: Letra Capital Editora, 2016.

JOÃO PESSOA. Onibus de João Pessoa, Pontos e Rotas, 2017. Disponível em: http://www. onibusjp.com. Acesso em: 1 ago. 2017.

MAIA, D. S. e DE LUCENA, W. G. "A expansão periférica e a habitação popular nas cidades do interior do território brasileiro: o processo de urbanização recente em cidades de distintas escalas geográficas - Campina Grande e Patos na Paraíba”. In: BELLET, Carmen et al. (Org.) Urbanización, producción y consumo en ciudades medias/intermedias Urbanização, produção e consumo em cidades médias/intermediárias. pp. 339-71, 2015.

MIRANDA, L. I. B. Empreendimentos Habitacionais em Espaços Periféricos: desafios para $o$ planejamento territorial integrado, Pesquisa Universal 2014/2017, (Relatório de Pesquisa, Edital MCTI/CNPq/UNIVERSAL No 11/2014 - Processo 461933/2014-4), 2018.

OBSERVATÓRIO DAS METRÓPOLES. Desafios para a politica habitacional: $2^{a}$ etapa do programa Minha Casa, Minha Vida. Disponível em: http://observatoriodasmetropoles. net/. Acesso em: 20 Dez. 2017.

ROLNIK, R. (Coord.). Ferramentas para avaliação da inserção urbana dos empreendimentos do MCMV. (Relatório de Pesquisa). São Paulo: Universidade de São Paulo; Laboratório Espaço Público e Direito à Cidade, 2014.

SANTO AMORE, C. S. et al (Org.). Minha Casa...e a Cidade? Avaliação do Programa Minha Casa Minha Vida em Seis Estados Brasileiros. Rio de Janeiro: Letra Capital, 2015. 